\title{
DISCUSSION AND REPLY
}

\section{The Age of the Potassic Alkaline Igneous Rocks along the Ailao Shan-Red River Shear Zone: Implications for the Onset Age of Left-Lateral Shearing: A Discussion}

\author{
Sun-Lin Chung, Michael P. Searle, ${ }^{1}$ and Meng-Wang Yeh ${ }^{2}$ \\ Department of Geosciences, National Taiwan University, Taipei 106, Taiwan \\ (e-mail: sunlin@ntu.edu.tw)
}

Liang et al. (2007) reported new U-Pb zircon age data of 12 potassic alkaline intrusions along the Ailao Shan-Red River (ASRR) shear zone and concluded that the ages, ranging from 36.3 to $34.0 \mathrm{Ma}$, date the initiation of the ASRR left-lateral movement. Although there are numerous articles suggesting this link between alkaline magmatism and strike-slip faulting (e.g., Tapponnier et al. 1982; Schärer et al. 1990, 1994; Leloup et al. 1993, 1995, 2001; Zhang and Schärer 1999|, we address in this discussion several lines of key evidence that do not support the link. We propose instead that $(a)$ there is no spatial or genetic relation between alkaline igneous intrusions and the ASRR shear zone and $(b)$ the alkaline rocks that intruded within, close to, or away from the shear zone were formed before left-lateral shearing, and thus their $\mathrm{U}-\mathrm{Pb}$ ages cannot serve as direct time constraints on the initiation of the fault zone.

By noting that "previous studies have suggested that Cenozoic magmatic activity within the ASRR shear zone was genetically related to the ductile deformation and high-grade metamorphism associated with movements on the shear zone" despite the fact that "there are also intrusions emplaced into unmetamorphosed sediments that are close to but outside the ASRR shear zone," Liang et al. (2007, p. 232) argued that "the close spatial relationship between the potassic alkaline intrusions and the ASRR shear zone implies a genetic relationship between the two. The age of these rocks can therefore provide better constraints on the on-

\footnotetext{
Manuscript received October 10, 2007.

${ }^{1}$ Department of Earth Sciences, Oxford University, Parks Road, Oxford OX1 3PR, United Kingdom.

${ }^{2}$ Department of Earth Sciences, National Taiwan Normal University, Taipei, Taiwan.
}

set of movement on the ASRR." The argument is problematic and, in our opinion, most likely untrue. There are three types of intrusions within the shear zone: (1) calc-alkaline granodiorite-granites that form the protolith of many of the high-grade gneisses, (2) alkaline rocks of monzonite-syenite lithologies, and (3) leucogranites that crystallized from crustal melts. As already pointed out by Searle (2006), the majority of these intrusions were prekinematic with respect to left-lateral shearing. Besides, only minor amounts of alkaline intrusions are located within the high-grade gneisses, and most potassic alkaline igneous rocks occur in the unmetamorphosed sedimentary sequences outside or well away from the shear zone (Chung et al. 1997, 1998; Xu et al. 2001; Searle 2006).

The largest of the alkaline rocks, for example, is the FanSiPan alkaline granite-syenite in northern Vietnam, which has a U-Pb titanite age of $35.2 \pm$ 0.4 Ma (Zhang and Schärer 1999). The FanSiPan syenite is located $15-20 \mathrm{~km}$ southwest of the ASRR shear zone and is separated from the shear zone by undeformed older granodioirites (PoSen batholith) and by sedimentary red beds and metamorphosed rocks of the Sapa unit (Searle 2006). The FanSiPan syenite, importantly, is largely undeformed and crosscut only by a few minor left-lateral faults with small offsets. There is no spatial or temporal link between the FanSiPan intrusion and strike-slip shearing. Moreover, $\sim 10 \mathrm{~km}$ south of the FanSiPan syenite, there is another suite of potassic igneous rocks coined as the PuSamCap complex, comprising small, undeformed intrusive and subvolcanic bodies with heterogeneous compositions from mafic to felsic (Phan 1991; Chung et al. 1997). The PuSamCap complex, active during 36 and $29 \mathrm{Ma}$ based on Ar-Ar dates (Chung et al. 1998), is not

[The Journal of Geology, 2008, volume 116, p. 201-204] @ 2008 by The University of Chicago. All rights reserved. 0022-1376/2008/11602-0008\$15.00. DOI: 10.1086/527458 


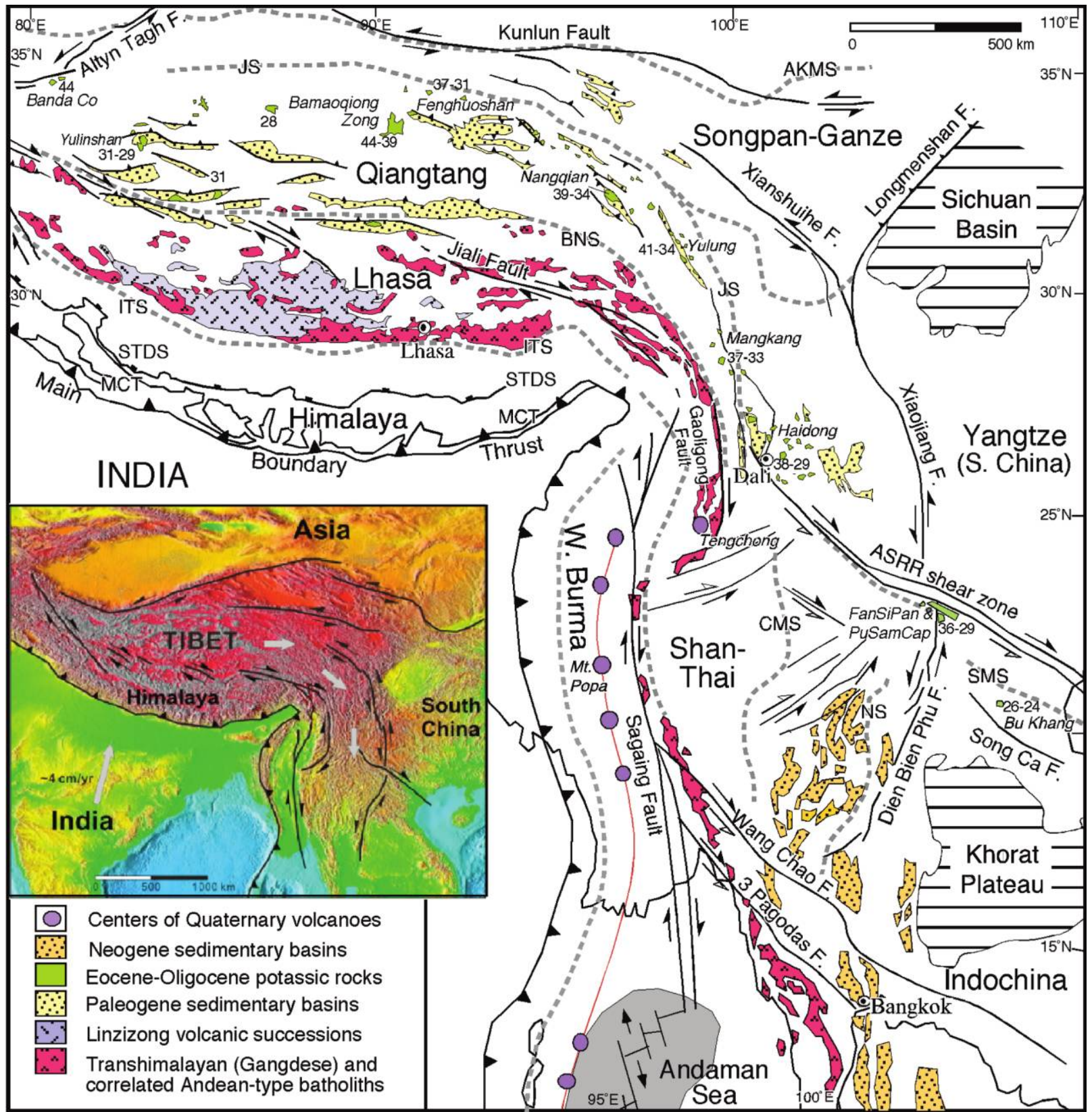

Figure 1. Simplified tectonic map showing the distribution of mid-Eocene to Oligocene potassic alkaline rocks from northern Tibet to northern Indochina. Modified from Chung et al. (2005). AKSM = Ayimaqin Kunlun Muztagh suture; $B N S=$ Bangong Nujian suture; $C M S=$ Changning Menglian suture; $I T S=$ Indus Tsangpo suture; $I S=$ Jinshan suture; $M C T=$ Main Central Thrust; $N S=$ Nan suture; $S M S=$ Song Ma suture; STDS = South Tibet Detachment System.

only coeval with but also geochemically comparable to the Haidong complex near Dali, southwest Yunnan, from which nine out of the 12 dated samples reported by Liang et al. (2007) were recovered. In both the PuSamCap and Haidong complexes, there are highly magnesian potassic rocks, with $\mathrm{SiO}_{2}, \mathrm{MgO}$, and $\mathrm{K}_{2} \mathrm{O}$ contents of $\sim 50 \mathrm{wt} \%,>10$ $\mathrm{wt} \%$, and $>6 \mathrm{wt} \%$, respectively, that originated most likely from a phlogopite-bearing, metasomatized lithospheric mantle source (e.g., Chung et al. 1997; Xu et al. 2001) and can hardly be explained by the "shear heating" hypothesis (see Searle 2006 for detail).

Regarding the generation of the potassic alkaline 
rocks, Liang et al. (2007, p. 237) were perhaps right in stating that "the similarity in their major element compositions, trace element patterns, and Sr$\mathrm{Nd}-\mathrm{Pb}$ isotopic compositions requires a common genesis for these rocks" but incorrect in assuming that "potassic alkaline igneous rocks with the same geochemical characteristics are not found outside this belt." The alkaline rocks are not restricted to the ASRR shear zone, and, as depicted by Chung et al. $(1998,2005)$, are related to a regional phase of mid-Eocene to Oligocene potassic magmatism throughout northern Tibet extending to Yunnan and Vietnam, with ages ranging between ca. 44 and $24 \mathrm{Ma}$ (fig. 1). These may include the alkaline granites, dated at 26-24 Ma (Nagy et al. 2000), that occur in association with the Bu Khang extensional gneiss dome in central Vietnam (Jolivet et al. 1999). In northern Tibet, emplacement of the potassic magmas was associated with development of numerous large sedimentary basins (fig. 1), which show a dominant east-west elongation implying regional north-south extension (Chung et al. 2005). This relation, together with the widespread occurrence of high-Mg potassic rocks, does not support the argument that the potassic alkaline magmatism was confined to major strike-slip fault zones in the region and thus controlled by crustal deformation, but it rather points to regional cause for lithospheric extension involving dynamic mantle processes.

Structural and geochronological data from the ASRR shear zone, as reevaluated by Searle (2006), show that the deformation history of this shear zone is considerably more complex than shown in the model of Leloup et al. (1993, 1995, 2001). During our recent fieldwork in the Diancang Shan and Ailao Shan in 2007, we confirmed the view that all the calc-alkaline and potassic alkaline granites and most leucogranites within the ASRR shear zone are prekinematic because these rocks show high-temperature ductile fabrics, boudinage, and folding features imposed after crystallization of the magmas. Initiation of the left-lateral strike-slip faulting along the ASRR shear zone, therefore, cannot be constrained by zircon U-Pb ages, i.e., magma crystallization ages, obtained from either deformed or undeformed potassic alkaline igneous rocks that, respectively, are located within and outside the ASRR shear zone.

\section{RE F E R E N C E S C I T E D}

Chung, S.-L.; Chu, M.-F.; Zhang, Y.; Xie, Y.; Lee, T.-Y.; Lo, C.-H.; Li, X.-H.; Lan, C.-Y.; Zhang, Q.; and Wang, Y. 2005. Tibetan tectonic evolution inferred from spatial and temporal variations in post-collisional magmatism. Earth Sci. Rev. 68:173-196.

Chung, S.-L.; Lee, T.-Y.; Lo, C.-H.; Wang, P.-L.; Chen, C.Y.; Nguyen, T. Y.; Tran, T. H.; and Wu, G. 1997. Intraplate extension prior to continental extrusion along the Ailao Shan-Red River shear zone. Geology 25: 311-314.

Chung, S.-L.; Lo, C.-H.; Lee, T.-Y.; Zhang, Y.; Xie, Y.; Li, X.-H.; Wang, K.-L.; and Wang, P.-L. 1998. Diachronous uplift of the Tibetan plateau starting $40 \mathrm{Myr}$ ago. Nature 394:769-773.

Jolivet, L.; Maluski, H.; Beyssac, O.; Goffé, B.; Lepvrier, C.; Phan, T. T.; and Nguyen, V. V. 1999. OligoceneMiocene $\mathrm{Bu}$ Khang extensional gneiss dome in Vietnam: geodynamic implications. Geology 27:67-70.

Leloup, P. H.; Arnaud, N.; Lacassin, R.; Kienast, J.-R.; Harrison, T. M.; Phan, T.; Replumax, T. T.; and Tapponnier, P. 2001. New constraints on the structure, thermochronology and timing of the Ailao Shan-Red River shear zone. J. Geophys. Res. 106:6683-6732.

Leloup, P. H.; Harrison, T. M.; Ryerson, F. J.; Chen, W.; Li, Q.; Tapponnier, P.; and Lacassin, R. 1993. Structural, petrological and thermal evolution of a Tertiary ductile strike-slip shear zone, Diancang Shan, Yunnan. J. Geophys. Res. 98:6715-6743.

Leloup, P. H.; Lacassin, R.; Tapponnier, P.; Schärer, U.;
Zhong, D.; Liu, X.; Zhang, L.; and Trinh, P. H. 1995. The Ailao Shan-Red River shear zone (Yunnan, China), Tertiary transform boundary of Indochina. Tectonophysics 251:3-84.

Liang, H.-Y.; Campbell, I. H.; Allen, C. M.; Sun, W.-D.; Yu, H.-X.; Xie, Y.-W.; and Zhang, Y.-Q. 2007. The age of the potassic alkaline igneous rocks along the Ailao Shan-Red River shear zone: implications for the onset age of left-lateral shearing. J. Geol. 115:231-242.

Nagy, E. A.; Schärer, U.; and Nguyen, T. M. 2000. OligoMiocene granitic magmatism in Central Vietnam and implications for continental deformation in Indochina. Terra Nova 12:67-76.

Phan, C. T. 1991. Geology of Campuchea, Laos, and Vietnam. Hanoi, Geol. Surv. Vietnam, 158 p.

Schärer, U.; Tapponnier, P.; Lacassin, R.; Leloup, P. H.; Zhong, D.; and Ji, S. 1990. Intraplate tectonics in Asia: a precise age for large-scale Miocene movement along the Ailao Shan-Red River shear zone, China. Earth Planet. Sci. Lett. 97:65-77.

Schärer, U.; Zhang, L.-S.; and Tapponnier, P. 1994. Duration of strike-slip movements in large shear zones: the Red River belt, China. Earth Planet. Sci. Lett. 126: 379-397.

Searle, M. P. 2006. Role of the Red River shear zone, Yunnan and Vietnam, in the continental collision of SE Asia. J. Geol. Soc. Lond. 163:1025-1036.

Tapponnier, P.; Peltzer, G.; Armijo, R.; Le Dain, A. Y.; and Cobbold, P. 1982. Propagating extrusion tectonics 
in Asia: new insights from simple experiments with plasticine. Geology 10:611-616.

Xu, Y.-G.; Menzies, M. A.; Thirlwall, M. F.; and Xie, G.H. 2001. Exotic lithospheric mantle beneath the western Yangtze craton: petrogenetic links to Tibet using highly magnesian ultrapotassic rocks. Geology 29: 863-866.

Zhang, L.-S., and Schärer, U. 1999. Age and origin of magmatism along the Cenozoic Red River shear belt, China. Contrib. Mineral. Petrol. 134:67-83. 